\title{
Ethnoveterinary study of medicinal plants used for cattle treatment in Bojonegoro District, East Java, Indonesia
}

\author{
ANGGI MUHTAR PRATAMA ${ }^{1, \bullet}$, OKTI HERAWATI ${ }^{2,3}$, ALIFAH NUHA NABILA ${ }^{1}$, \\ THEODORA ATHALIA BELINDA ${ }^{1}$, AGUSTINA DWI WIJAYANTI ${ }^{1}$ \\ ${ }^{1}$ Department of Pharmacology, Faculty of Veterinary Medicine, Universitas Gadjah Mada. J1. Fauna, No. 2, Caturtunggal, Sleman 55281, Yogyakarta, \\ Indonesia, Tel.: +62-274-6492088, 560862, Fax.: +62-274-560861, `email: anggi.muhtar.p@ mail.ugm.ac.id \\ ${ }^{2}$ Department of Microbiology, Faculty of Veterinary Medicine, Universitas Gadjah Mada. J1. Fauna No. 2, Caturtunggal, Sleman 55281, Yogyakarta, \\ Indonesia \\ ${ }^{3}$ Bacteriology Laboratory, Faculty of Veterinary Medicine, Universiti Putra Malaysia. Jln. Mardi-UPM, Seri Kembangan, Selangor 43400, Malaysia
}

Manuscript received: 23 August 2021. Revision accepted: 20 September 2021.

\begin{abstract}
Pratama AM, Herawati O, Nabila AN, Belinda TA, Wijayanti AD. 2021. Ethnoveterinary study of medicinal plants used for cattle treatment in Bojonegoro District, East Java, Indonesia. Biodiversitas 22: 4236-4245. Bojonegoro is a rural district in Indonesia's East Java Province where farming and cattle rearing are the main economic activities. The Bojonegoro District's cattle producers employ some medicinal plants specifically for the treatment of bovine illnesses. However, no data has been reported thus far. The goal of this research was to find and document ethnoveterinary medicinal herbs for cattle cures in the Bojonegoro District. A total of 41 cattle breeders were interviewed for the study. To collect demographic and ethnoveterinary medicinal plant data, each informant was interviewed using a semi-structured questionnaire in the native language of each informant. The stastitical analysis in this study include informant consensus (Fic), Fidelity Level (FL), and Plant Part Frequency (PPF). Approximately 78.00\% of the respondents are between the ages of 30 and 50, with $36.59 \%$ having only graduated from senior high school. The Peranakan Ongole (PO) is the most common breed preserved by cattle breeders. In the study area, 41 ethnoveterinary medicinal plants were mentioned by male respondents to cure cattle health problems. Digestive illnesses are the most frequent ailments in cattle treated with medicinal plants. Curcuma longa L. was the most commonly mentioned medicinal plant. A majority of the source ethnoveterinary medicinal plants were cultivated on-site and the leaves of these plants were most often used.
\end{abstract}

Keywords: Bojonegoro, cattle, cattle breeders, ethnoveterinary, medicinal plants

\section{INTRODUCTION}

Ethnoveterinary medicinal plant systems are widely practiced in cultures around the world, and they are affected by the community or ethnic group cultural traditions (Teka et al. 2020; Xiong and Long 2020). Knowledge of therapeutic plant techniques for both animals and humans is a precious asset for indigenous people in developing countries (Bakare et al. 2019). The World Health Organization (2010) estimated that Traditional medicine is used by $60.00 \%$ of the world's population to regulate and treat various diseases. Rural communities adopt traditional plant practices for a variety of reasons, including the local availability of native medicinal plants, absence of side effects, ease of usage, and poor access to costly pharmaceuticals by rural people (Raza et al. 2014; Xiong and Long 2020). Medicinal plants are an invaluable resource for a country's human and animal health care systems, which can help to improve people's lives and livelihoods (Tolossa et al. 2013). Medicinal plants can play a potential role in the treatment of a variety of animal diseases (Dassou et al. 2020).

In Indonesia, medicinal plants play a major role in primary healthcare practices, particularly in rural areas (Jadid et al. 2020). When producing medicines, Indonesians use either a single plant or a mix of plants known as jamu, including minerals added on occasion (Rahayu et al. 2020). Traditional medicine in Indonesia has a long history, involving a wide diversity of plants, animal products, and minerals. After the Amazon rainforests, Indonesia has the world's second-highest level of biodiversity, as evidenced by a large variety of indigenous medicinal plants. Indonesian tropical forests span around 143 million hectares and are home to approximately $80.00 \%$ of the world's medicinal plants. There are over 2500 medicinal plant species (Elfahmi et al. 2014; Sujarwo et al. 2015; Jadid et al. 2020).

For many generations, the cattle breeders community in Bojonegoro District, East Java province, Indonesia, has used ethnoveterinary medicinal plants. This information was passed down to them from their forefathers. Traditional medicines for treating cattle have been used in these cultures for a long time. The community only consumes a variety of herbal plants that may be easily found in the area where they live. Unfortunately, indigenous knowledge of the use of herbal medicines to treat cattle has never been recorded. Until now, only a few people in the community had access to this knowledge. Nowadays, however, sharing ethnoveterinary medicinal plant information is uncommon, and fewer young people are engaged in this profession. 
In light of this current situation, it is important to record the various kinds of medicinal plants being used by the cattle breeding community for the treatment of cattle diseases. This research aims to provide recommendations for the conservation of local medicinal plants widely used, resulting in increased availability in nature and providing a scientific foundation for the perpetuation of research on local medicinal plants in the Bojonegoro District.

\section{MATERIALS AND METHODS}

\section{Study area}

Bojonegoro is a district in East Java, Indonesia (Figure 1), located 110 kilometers from Surabaya, the provincial capital, situated between 60 59' and 70 37' S and $112025^{\prime}$ and 1120 09' E, and around 115 meters above sea level. The area is characterized by a lowland plain with two seasons: a wet season from October to March and a dry season from April to September. The average annual rainfall is $1716 \mathrm{~mm}$, with humidity ranging from 60.00 to 90.00 percent and temperatures ranging from 24 to 32 degrees Celsius (Badan Pusat Statistik Kabupaten Bojonegoro, 2015). The district of Bojonegoro is consists of 28 sub-districts and 430 villages. With a total area of $2,198.79 \mathrm{~km}^{2}$ and a population density of 912 people per $\mathrm{km}^{2}$, the Bojonegoro District has $1,313,722$ people. The animal populations in the Bojonegoro District, according to Badan Pusat Statistik Kabupaten Bojonegoro (2016), include 201,953 cattle, 19,000 dairy cows, 105,013 goats, and 129,990 sheep. Around $39.52 \%$ of residents over 15 work in the agricultural-livestock sector, followed by $38.31 \%$ in services and $22.17 \%$ in industry (Badan Pusat Statistik Kabupaten Bojonegoro 2018).

\section{Procedures}

Study design and sampling methods

Interviews with cattle breeder communities in the Bojonegoro District area were conducted from July 6 to July 26, 2020. Data of cattle breeders were collected from the Department of Animal Husbandry and Fisheries in Bojonegoro. Because the respondents are from the Javanese community, the interviews were conducted in English and then translated into Indonesian and Javanese using semi-structural questionnaires and a random sampling method for informants who represent members of a cattle breeders group that has been in existence for more than three years. This activity necessitates the use of data as a source of information to provide an overview of cattle breeders' knowledge and experience with medicinal plant treatments for treated animals.

\section{Data collection}

Gender, age, degree of education, job, number of cattle owned, and farming experience were among the demographic data collected from cattle breeder interviews. Local names of medicinal plants, parts of medicinal plants used, formulation, route of action, volume, duration of drug administration, disease treated, source, conservation status, and economic analysis are some of the ethnoveterinary medicinal plant data collected from the informants. There was also a search for further information in specific names of herbal medicine on theplantlist.org assigned to these plants. Data processing was carried out by recording and analyzing the information collected from the cattle breeders. Data from the interviews was gathered and organized in a table (Aziz et al. 2018; Raza et al. 2014; Tariq et al. 2014).

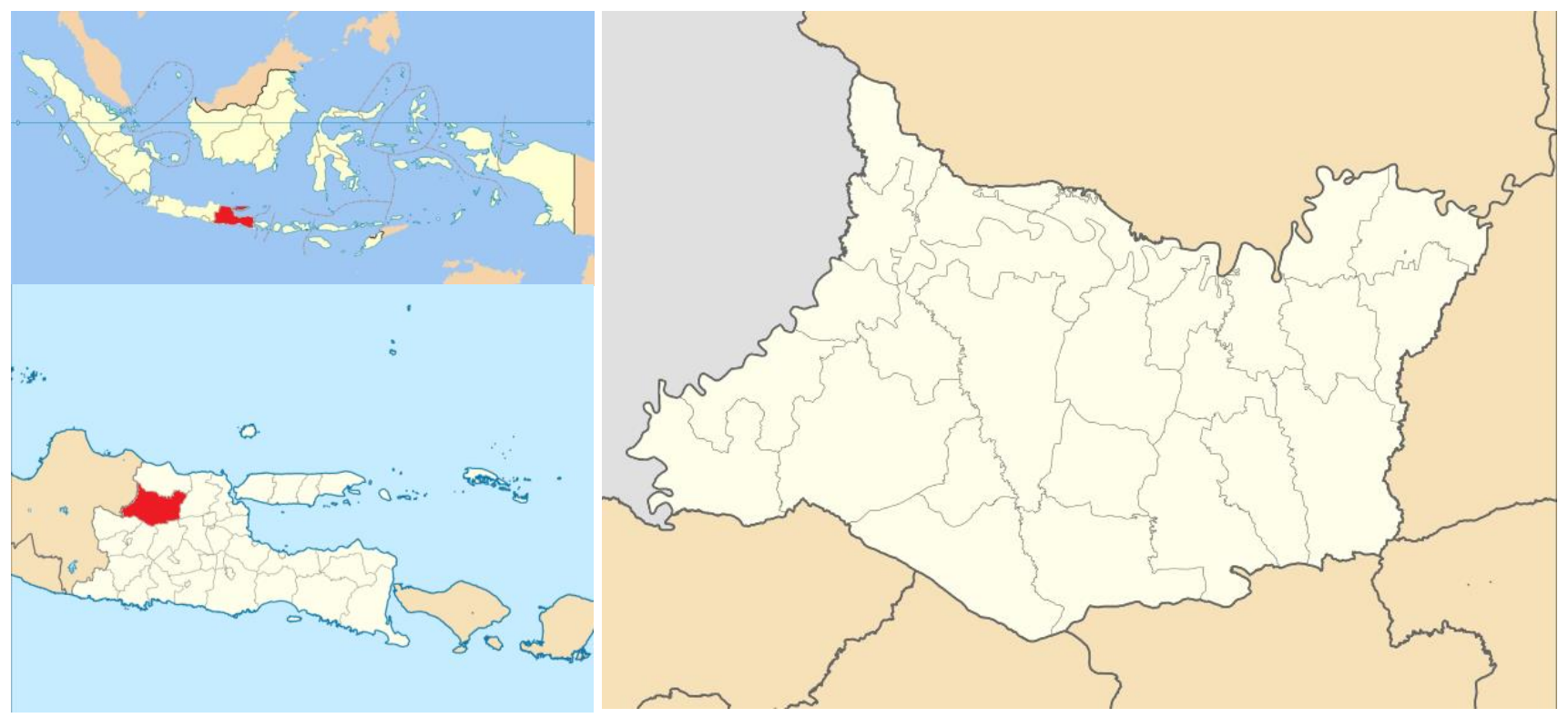

Figure 1. Maps of Bojonegoro District, East Java Province, Indonesia 


\section{Statistical analysis}

In this study, to evaluate inter- informant consensus (Fic) we used the method used by Tariq et al (2014), namely:

$$
\text { Fic }=\frac{\text { nur }-\mathrm{nt}}{\text { nur-1 }}
$$

Where:

nur : number of used citations in every category

nt : number of the medicinal plants used

Fidelity Level (FL) analysis was calculated following the study procedures by Jadid et al. (2020) to discover information consistency between informants about the use of particular medicinal plants to treat certain disorders/diseases in cattle. The formula used to measure the percentage of FL is:

$$
\mathrm{FL}(\%)=\frac{\mathrm{NP}}{\mathrm{N}} \times 100 \%
$$

Where:

$\mathrm{NP}$ : informants who revealed a medicinal plant to treat a specific disease/disorder

$\mathrm{N}$ : Total number of informants who mentioned the same medicinal plant for the treatment of the same disease/disorder

Plant Part Frequency (PPF) was calculated to determine the relative frequency of use of a medicinal plant's particular part for the treatment of disease/disorders, following Jadid et al. (2020):

$$
\operatorname{PPF}(\%)=\frac{\sum R U(\text { plant part })}{\sum R U} \times 100
$$

Where:

$\sum \mathrm{RU}$ (plant part): sum of the cited medicinal plant parts plant

$\sum \mathrm{RU}$ : total number of cited uses for a given medicinal

\section{RESULTS AND DISCUSSION}

\section{Demographic data of informants}

Bojonegoro District is one of the largest cattleproducing areas in Indonesia's East Java province. The majority of people living in rural areas prefer to work as cattle breeders. Although the breeding process is carried out by organized groups centralized in each area, their breeding management is still highly traditional. The barn is a semi-permanent structure made from scrap wood, demonstrates this, as does the poor handling of animal feed and trash. Cattle breeders still believe that medicinal plants help to cure many diseases in their cattle, in addition to more established animal health management practices. If one's livestock is seriously ill or dying, they will call a veterinarian. Cattle breeders always have a heifer nurtured until they give birth to a calf using artificial insemination.
The calf is raised for 3 to 12 months before being sold. If a breeder's productivity decreases, they will replace the heifer with new ones. The majority of respondents declare that raising cattle is not for profit but instead is a method of saving wealth for future needs. This concept is known as rojokoyo. A number of cattle breeders may sell their cattle to pay for school registration fees, weddings or circumcisions, and Eid al-Adha celebrations.

Even though they have other animals such as chickens, ducks, geese, and pigeons, most cattle breeders in Bojonegoro District have devoted their lives to cattle breeding. These animals are used as a source of protein for daily needs or as pets. The degree of wealth is determined by cattle ownership. Cattle raising can also be seen as an ancestral cultural mandate that must be preserved. A thanksgiving ceremony known as brokohan is held when a cow is born. This small celebration is held to thank God for their good fortune and pray for the newborn calf's wellness. There are no records of when ethnoveterinary therapy of cattle began. However, cattle breeders have noticed it since they were children from their grandparents. Because of the hot weather in the Bojonegoro District all year, they prefer to keep tropical cattle such as peranakan ongole (PO). Although they are gradually accepting other breed cattle, such as limousine, simmental, brahman, brahman cross, and mix breed, their numbers are still low.

All the respondents were males, with the primary occupation being farmer and cattle breeders. On average, each respondent has five cattle. Seventy-eight percent of the participants aged 30 to 50 years old, while $12.00 \%$ are older than 50 years old and $4.00 \%$ are younger than 30 years old. A senior high school diploma is held by $36,59 \%$ of cattle breeders, followed by the highest level of education obtained being a junior high school diploma $(24.39 \%)$ or an elementary school education $(19.51 \%)$. Meanwhile, only $17.07 \%$ of students were able to continue their education to the undergraduate level and $2.44 \%$ to the master's level. Around $59.00 \%$ of the respondents have worked as cattle breeders for less than ten years, $24.00 \%$ have worked as cattle breeders for more than 20 years. Only $17.00 \%$ have worked as cattle breeders for 10 to 20 years. About $59.00 \%$ of cattle in the Bojonegoro District are Peranakan ongole, while $41.00 \%$ are mixed breeds (PO, limousine, simmental, brahman). Adults of all breeds have a bodyweight of between 400 and 600 kilograms. The main source of food is the grass that grows wild near the barn, field, and along riverbanks. Some concentrates such as high protein feed (amino acid, ureum) and minerals such as calcium, magnesium, and phosphor are sometimes added sufficiently to the feed.

\section{Ethnoveterinary medicinal plant data}

Table 1 presents the 41 ethnoveterinary medicinal plants mentioned by the 41 respondents to treat cattle diseases in the study area. Cultivation $(65.80 \%)$, wild $(31.70 \%)$, and traditional market purchases $(4.80 \%)$ were the main sources of medicinal plants in the Bojonegoro District. 
Table 1. Ethnoveterinary medicinal plants used for the treatment of cattle ailments in Bojonegoro District

\begin{tabular}{|c|c|c|c|c|c|}
\hline Family & Scientific name & Local name & Using part & Treated disease & Source \\
\hline \multirow[t]{8}{*}{ Zingiberaceae } & Alpinia galanga $(\mathrm{L})$ Wild & Laos & Rhizome & Digestion (stimulate appetite) & Cultivate \\
\hline & Curcuma aeruginosa Roxb. & Temuireng & Rhizome & Digestion (stimulate appetite, bloating) & Cultivate \\
\hline & Curcuma longa $\mathrm{L}$. & Kunyit, kunir & Rhizome & Digestion (bloating, stimulate appetite) & Cultivate \\
\hline & Curcuma xanthorrhiza Roxb & Temulawak & Rhizome & Digestion (bloating, stimulate appetite) & Cultivate \\
\hline & $\begin{array}{l}\text { Curcuma zedoaria (Christm.) } \\
\text { Roscoe }\end{array}$ & Kunyit putih & Rhizome & $\begin{array}{l}\text { Digestion ((bloating, stimulate appetite), } \\
\text { body warmers }\end{array}$ & Cultivate \\
\hline & Kaempferia galanga $\mathrm{L}$. & Kencur & Rhizome & Digestion (stimulate appetite) & Cultivate \\
\hline & $\begin{array}{l}\text { Zingiber montanum (J. } \\
\text { Koenig) Link ex A.Dietr. }\end{array}$ & Bangle & All & Digestion (stimulate appetite, bloating) & Wild \\
\hline & Zingiber officinale Roscoe & Jahe & Rhizome & $\begin{array}{l}\text { Digestion (stimulate appetite, bloating), } \\
\text { body warmers }\end{array}$ & Cultivate \\
\hline \multirow[t]{4}{*}{ Fabaceae } & $\begin{array}{l}\text { Leucaena leucocephala } \\
\text { (Lam.) de Wit }\end{array}$ & $\begin{array}{l}\text { Mlanding/ } \\
\text { mlandingan/ } \\
\text { lamtoro }\end{array}$ & Leaf & $\begin{array}{l}\text { Digestion (diarrhea), Integument } \\
\text { (wound healing) }\end{array}$ & Cultivate \\
\hline & Pachyrhizus erosus (L.) Urb. & Bengkoang & Root Tubers & Digestion (stimulate appetite) & Cultivate \\
\hline & $\begin{array}{l}\text { Sesbania grandiflora }(\mathrm{L} .) \\
\text { Pers. }\end{array}$ & Turi & Leaf & Lactation & $\begin{array}{l}\text { Cultivate, } \\
\text { wild }\end{array}$ \\
\hline & Tamarindus indica $\mathrm{L}$. & Asam Jawa & Leaf, fruit & Digestion (diarrhea), Respiratory & Cultivate \\
\hline \multirow[t]{4}{*}{ Poaceae } & $\begin{array}{l}\text { Cymbopogon citratus (DC.) } \\
\text { Stapf }\end{array}$ & Serai & Leaf & Digestion (stimulate appetite) & Cultivate \\
\hline & $\begin{array}{l}\text { Gigantochloa verticillata } \\
\text { (Willd.) Munro }\end{array}$ & Bambu & Leaf & Digestion (diarrhea, detoxification) & Cultivate \\
\hline & Imperata cylindrica $(\mathrm{L}$.$) Raeusch$ & Ilalang & Leaf & Digestion (diarrhea) & Wild \\
\hline & Saccharrum officinarum L. & Tebu & Stem & Digestion (detoxification) & Buy \\
\hline \multirow[t]{2}{*}{ Euphorbiaceae } & Euphorbia hirta L. & Patikan kebo & Leaf & Integument (wound healing) & Wild \\
\hline & Jatropha multifida $\mathrm{L}$. & Yodium & Sap & Integument (wound healing) & Wild \\
\hline \multirow[t]{2}{*}{ Lamiaceae } & Ocimum sanctum $\mathrm{L}$. & Kemangi & Leaf & Digestion (stimulate appetite) & Cultivate \\
\hline & Tectona grandis L.f. & Jati & Young leaves & Integument (wound healing) & Cultivate \\
\hline \multirow[t]{2}{*}{ Piperaceae } & Piper betle L. & Sirih/Suruh & Leaf & $\begin{array}{l}\text { Digestion (diarrhea, detoxification), } \\
\text { Integument (wound healing) }\end{array}$ & Cultivate \\
\hline & Piper nigrum $\mathrm{L}$. & Merica, lada & Seed & Body warmers & Cultivate \\
\hline \multirow[t]{2}{*}{ Pandanaceae } & $\begin{array}{l}\text { Pandanus tectorius } \\
\text { Parkinson ex Du Roi }\end{array}$ & Pandan & Leaf & Lactation & Cultivate \\
\hline & Pandanus amaryllifolius Roxb. & Empol pandan & Rhizome & Lactation & Cultivate \\
\hline Acanthaceae & Androgaphis paniculata Ness & Sambiloto & Leaf & Digestion (stimulate appetite) & Wild \\
\hline Amaryllidaceae & Allium cepa $\mathrm{L}$. & Bawang merah & Root-tubers & $\begin{array}{l}\text { Digestion (stimulate appetite), } \\
\text { Integument (wound healing) }\end{array}$ & Cultivate \\
\hline Annonaceae & Annona squamosa $\mathrm{L}$ & Srikaya & Leaf & Digestion (anthelmintic) & Cultivate \\
\hline Apocynaceae & $\begin{array}{l}\text { Rauwolfia serpentina }(\mathrm{L} .) \\
\text { Benth. ex Kurz }\end{array}$ & Tule pandak & Root & Integument (smooths fur) & Wild \\
\hline Araceae & $\begin{array}{l}\text { Amorphophallus muelleri } \\
\text { Blume }\end{array}$ & Porang hutan & Leaf & Digestion (stimulate appetite) & Wild \\
\hline Arecaceae & Cocos nucifera $\mathrm{L}$. & Kelapa hijau & $\begin{array}{l}\text { Coconut } \\
\text { water }\end{array}$ & Digestion (detoxification) & Buy \\
\hline Asteraceae & Elephantopus scaber L. & Tapak liman & Leaf & Digestion (stimulate appetite) & Wild \\
\hline Convolvulaceae & Ipomoea batatas (L.) Lam. & Ketela rambat & Leaf & Lactation & Cultivate \\
\hline Costaceae & $\begin{array}{l}\text { Costus speciosus (J. Koenig) } \\
\text { Sm. }\end{array}$ & Dangkel pacing & Stem, leaf & Digestion (anthelmintic), Lactation & Wild \\
\hline Musaceae & Musa sapientum $\mathrm{L}$. & Pisang raja & Young fruit & Integument (wound healing, snake bite) & Cultivate \\
\hline Myrtaceae & Psidium guajava $\mathrm{L}$. & Jambu biji & Leaf & Digestion (diarrhea) & Cultivate \\
\hline Oxalidaceae & Averrhoa bilimbi L. & Belimbing wuluh & Fruit & Digestion (stimulate appetite) & Cultivate \\
\hline Phyllanthaceae & $\begin{array}{l}\text { Sauropus androgynus (L.) } \\
\text { Merr. }\end{array}$ & Babing/katuk & Leaf & Lactation & Cultivate \\
\hline Portulacaceae & Portulaca oleraceae L & Krokot & Leaf & Lactation & Wild \\
\hline Rubiaceae & Paederia foetida $\mathrm{L}$. & Simbukan/Sembukar & Leaf & Digestion (stimulate appetite, bloating) & Wild \\
\hline Sapotaceae & $\begin{array}{l}\text { Manilkara zapota }(\mathrm{L} .) \\
\text { P.Royen }\end{array}$ & Sawo & Leaf & Digestion (diarrhea) & Cultivate \\
\hline Simaroubaceae & Brucea javanica (L.) Merr. & Kwalot & Leaf & $\begin{array}{l}\text { Digestion (stimulate appetite, diarrhea; } \\
\text { anthelmintic) }\end{array}$ & Wild \\
\hline
\end{tabular}


According to the International Union for Conservation of Nature (IUCN), all of the medicinal plants mentioned by the informant are not endangered, indicating that their populations in nature are still vast. Furthermore, these herbal plants have the potential to be used in large quantities. The majority of respondents stated that medicinal plants are administered by oral solution formulation, with an average administration duration of 2-3 days and an average volume of 0.5-1.5 liters per dose. According to the results of the economic analysis, giving medicinal plants to cattle is significantly cheaper, safer, and effective for treating disorders/diseases with mild to moderate symptoms.

According to Table 2, gastrointestinal disorders are the most common condition that medicinal plants treat. The major concerns in the gastrointestinal tract are stimulating appetite (0.78), bloating (0.75), and detoxification (0.70). Apart from non-digestive disorders, lactation and wound healing are the most severe problems, with 0.71 and 0.68 , respectively. These diseases have a significant economic impact on cattle breeders because the appearance of the disease has a significant impact on the selling price of the cattle. Cattle breeders will be more aware of the major disease symptoms and will provide treatment derived from medicinal herbs when the symptoms first appear.

Curcuma longa L. was the most commonly mentioned medicinal plant species $(88.00 \%)$ for treating bloating, followed by Curcuma aeruginosa Roxb. (86.00\%) and Zingiber officinale Roscoe (82.00\%) for stimulating appetite (Table 3 ). Cattle breeders commonly use rhizome medicinal plants since they are easy to cultivate and found in the traditional market. Furthermore, it is affordable and well-known in the Javanese community as traditional medicine, also known as jamu empon-empon. Cattle breeders also believe that plants belonging to the Zingiberaceae family can cure a variety of diseases in both humans and animals based on empirical data. Cocos nucifera $\mathrm{L}$. infused in water is the most commonly used medicinal plant to treat various forms of poisoning in cattle. For a long time, this herb has been applied to protect humans from toxins. Cattle breeders most frequently mention the leaf of the Piper betle $\mathrm{L}$. as a natural ingredient for integumentum problem treatment. Meanwhile, Pandanus amaryllifolius Roxb. and Pandanus tectorius Parkinson ex Du Roi leaves are commonly used to strengthen lactation.

Table 4 presents which medicinal plant parts are usually used in Bojonegoro District: leaves $(58.90 \%)$, rhizome $(20.50 \%)$, root $(10.20 \%)$, fruit $(7.70 \%)$, stem $(5.10 \%)$, seed $(2.50 \%)$, and sap (2.50\%). Leaves were used most frequently because the majority of medicinal plants used by cattle breeders in Bojonegoro are trees. Although treatment derived from medicinal plant species using their rhizomes are the most commonly used. The use of the leaves, which are more abundant, is more sustainable, as it does not cause harm to the plants.

Table 2. Informant Consensus Factor (Fic) treatment categories

\begin{tabular}{lccc}
\hline \multicolumn{1}{c}{ Treatment categories } & Citations & $\begin{array}{c}\text { Number } \\
\text { of species }\end{array}$ & FIC \\
\hline Digestion (stimulate appetite) & 32 & 17 & 0.78 \\
Digestion (bloating) & 21 & 6 & 0.75 \\
Lactation & 22 & 7 & 0.71 \\
Digestion (detoxification) & 11 & 4 & 0.70 \\
Integumentum (wound healing) & 20 & 7 & 0.68 \\
\hline
\end{tabular}

Table 4. Plant Part Frequency (PPF) of medicinal plants used based ethnoveterinary medicinal study in Bojonegoro District, East Java, Indonesia

\begin{tabular}{lc}
\hline Parts & Frequency of parts $(\%)$ \\
\hline Leaves & 58.90 \\
Rhizome & 20.50 \\
Root & 10.20 \\
Fruit & 7.70 \\
Stem & 5.10 \\
Seed & 2.50 \\
Sap & 2.50 \\
\hline
\end{tabular}

Table 3. Fidelity Level (FL) of medicinal plants in Bojonegoro District, East Java, Indonesia

\begin{tabular}{llc}
\hline Plant species & Diseases/disorder categories & Fidelity level (\%) \\
\hline Curcuma longa L. & Digestion (bloating) & 88.00 \\
Curcuma aeruginosa Roxb. & Digestion (stimulate appetite) & 86.00 \\
Zingiber officinale Roscoe & Digestion (stimulate appetite) & 82.00 \\
Cocos nucifera L. & Digestion (detoxification) & 80.00 \\
Piper betle L. & Integumentum (wound healing) & 70.00 \\
Kaempferia galanga L. & Digestion (stimulate appetite) & 66.00 \\
Pandanus amaryllifolius Roxb. & Lactation & 66.00 \\
Pandanus tectorius Parkinson ex Du Roi & Lactation & 66.00 \\
Alpinia galanga (L) Wild & Digestion (stimulate appetite) & 60.00 \\
Curcuma xanthorrhiza Roxb. & Digestion (stimulate appetite) & 55.00 \\
\hline
\end{tabular}




\section{Discussion}

According to the data in Table 1, each medicinal plant species has a different function for the treatment of cattle disease. Medicinal plants mentioned by the respondents are all locally available Indonesian local plants. These plants are also easy to find and cultivate, particularly on the island of Java. They are cultivated by cattle breeders and used directly to treat cattle for many decades; however, some medicinal plants are still obtained from the forest or bought in traditional markets. This result of this study is consistent with those of Sargin and Büyükcengiz (2019) regarding the source of herbal medicine, mostly wild or cultivated. The use of medicinal plants for natural therapy is a part of their ancestral heritage. Plants familiar to the community and cultivated can also be found in the surrounding environment (Raza et al. 2014; Xiong and Long 2020; Yigezu et al. 2014). In this study, medicinal plants used for cattle therapy have been used very often by the Javanese community to overcome various human health problems. Later, when their cattle had problems, their ancestors tried to prescribe medicine by themselves. Their experimentation successfully cured the disease in cattle also. This knowledge was then passed on to their children and grandchildren, and thus it continues to be practiced today.

Under similar circumstances as in Indonesia, traditional medicines have been used for nearly $90.00 \%$ of livestock populations in Ethiopia, where complementary remedies are required in their modern health care system. All plants with pharmacological activity are complementarily prescribed as a good treatment for livestock diseases (Yigezu et al. 2014). Indeed, all across Africa also use medicinal plants are an important resource, if not the primary source of treatment: Benin, Rwanda, Tanzania, South Africa, and Uganda, for primary health care (Bakare et al. 2019; Dassou et al. 2020; McGaw et al. 2020; Yigezu et al. 2014; Sargin and Buyukcengiz 2019). Farmers who live in other regions also use medicinal plants for livestock, such as in the South Pacific Islands (Bakare et al. 2019), China (Xiong and Long 2020), Pakistan (Abbasi et al. 2013; Aziz et al. 2018; Khan et al. 2019; Raza et al. 2014), Turkey (Sargin and Buyukcengiz 2019), Europe (Schnyder et al. 2019), and Mesoamerica (Geck et al. 2020) and so forth. Among the most important medicinal plants used for treating animal diseases. Aloe sp., Cassia fistula, Podophyllum hexandrum, and Pogostemon benghalensis were the most important medicinal plants used for treating animal diseases as per use value in the study area of the North-Western Himalaya, India (Thakur et al. 2016). The alternative medicines from medicinal plants grown in the environment around a certain region or ethnicity are unique, having their characteristics. Those trusted for their efficacy are faithfully passed down and used by the descendants of that community.

Treatment for digestive disorders such as stimulating appetite, bloating and detoxification, the biggest problems in cattle, that are treated with medicinal plants by FIC value 0.74 respectively. These findings are consistent with the results of various other ethnoveterinary medicine studies showing that digestion-related disease is a major focus of treatment with medicinal herbs in the Province of Giresun Turkey and with the same FIC value, 0.74 (Guler et al. 2021). Moreover, digestive problem in livestock in Buyi China, Jammu and Kashmir India, and Kohat Pakistan, the FIC value is above 0.80 (Sharma et al. 2012; Tariq et al. 2014). A number of domestic animals species in Buyi, China, are often treated by medicinal plants if clinical symptoms of the disorder appear, such as ruminal impaction, diarrhea, and abdominal pain. Massive disease attacks on the gastrointestinal system are caused by poor sanitation practices in closed environments (Sharma et al. 2012; Xiong and Long 2020). This problem can reduce the economic value of cattle. If not handled immediately, such ailments can cause death. Therefore, the medicinal plants that cattle breeders have long practiced have been essential to overcome various acute symptoms. However, if the disease is chronic, they will immediately call the veterinarian. Usually, the lack of appetite in cattle occurs due to changes in the type of feed, mainly at the change of seasons or when a calf begins to mature and become more independent. Bloating occurs when cattle eat leaves that are too young. This problem often occurs, especially in the rainy season. Some cattle breeders outsmart others by drying the grass before giving it to cattle, but this practice can not guarantee one hundred percent that cattle will be free from bloating problems. Concentrated diets that are too high compared to grass are also one of the problems causing bloating in cattle. Providing high concentrate feed is mostly undertaken by cattle breeders hoping that the Average Daily Growth (ADG) is high and cattle can develop quickly. Meanwhile, the main problem of poisoning in cattle is caused by accidentally eating poisonous plants, which are mixed in the vegetation when cattle breeders graze them in the fields, riverbanks, and forest. Cattle breeders mentioned accidentally mixing poisonous plants into animal feed also. On the other hand, there is still a lot of ignorance among young cattle breeders about plants that generally cause poisoning in cattle (Tariq et al. 2014; Schnyder et al. 2019; Xiong and Long 2020).

The medicinal plants most often used to treat digestive problems are species in the family Zingiberaceae (ginger). The most commonly used part for treating bloating is the rhizome of Curcuma longa L. (88.00\%). Numerous other species can be used to stimulate appetite, including the rhizome of Curcuma aeruginosa Roxb (86.00\%). This is similar to the results of Fidelity Level studies in which Zingiberaceae rhizomes were effectively used as a remedy for various digestive problems occurring in livestock, such as diarrhea, bloating, warming of the body, and anorexia more than 56\% (Asmara et al. 2018; Jayakumar et al. 2018; Palanichamy et al. 2018; Xiong and Long 2020). Observations of various livestock in India showed that the rhizome of Curcuma longa L. is also used to treat reproductive disorders, heal cracks in teats, abrasions, horn avulsion, hematomas, and blisters on the udder (Jayakumar et al. 2018). Another study indicated that $96,50 \%$ of respondents used Curcuma longa L. as an antiseptic to treat their livestock (Kirmani et al. 2020).

The Curcuma longa L. species is well-known in rural areas, particularly in Java. The plant's rhizome is frequently 
used in herbal mixtures and cooking spices (Elfahmi et al. 2014). Plants in the Zingiberaceae family are easy to grow in a variety of soil conditions, and they reproduce quickly. Curcuma longa $\mathrm{L}$. is used to treat digestive disorders in cattle, such as boosting appetite and reducing bloating. Because of its nutritional, pharmacological, and medicinal qualities, curcumin, a natural polyphenolic bioactive substance produced from Curcuma longa L., has been employed as an additive (Wang et al. 2017). Antiinflammatory, antioxidant, antibacterial, antiparasitic, and coccidiostat activities are all demonstrated in curcumin (Jaguezeski et al. 2018). A previous report from India showed that fresh Curcuma longa L. rhizomes and fresh Tamarindus Indica L. leaves are used to cure muscle tension in livestock (Jayakumar et al. 2018). Another study in human healthcare documented that Curcuma longa L. was also the most frequently used medicinal plant species by people in rural villages of West Java, Indonesia (Rahayu et al. 2020). Curcumin inhibits and minimizes pathogenic events by interacting with a wide range of molecules implicated in the inflammatory cascade (Tizabi et al. 2014). An increase in antioxidant enzyme activity usually results in a reduction in oxidative reactions, as well as oxidative stress and cellular damage reduction (Al-Rubaei et al. 2014). Research shows that curcumin added to dairy products provides increased antioxidant potential with a consequent improvement in storage stability. The antiinflammatory and antioxidant actions of curcumin already benefit the health of the sheep in this initial period of lactation and reduce somatic cell count (SCC) in the milk when the lactating sheep may experience metabolic disturbances and oxidative stress (Salinas-Rios et al. 2017; Jaguezeski et al. 2018).

Curcuma aeruginosa Roxb. is reputable in the Javanese community as a herbal medicine for rheumatism and hemorrhoid problems, while Zingiber officinale Roscoe is usually used as a body warmer, a relaxant of muscles, and anti-cough treatment. The rhizome of Curcuma aeruginosa Roxb. contains germacrone, furanodiene, curcumenol, zedoarol, zedoarondiol, zedoalactone A, zedoalactone B, isocurcumenol, and isofuranodiene. These are non-volatile compounds that are important as antioxidants, antibacterial, and anti-inflammatory agents. They can improve various problems in the digestive tract, such as colic, diarrhea, and gastritis (Hossain et al. 2015; Theanphong et al. 2015). The essential oil in the rhizome of Curcuma aeruginosa Roxb. is suspected to be the key factor causing appetite increase cattle. It causes the essential oil to emit a distinctive aroma specifically found in all rhizomes of the Zingiberaceae family of plants. Recently, a study by Nurcholis et al. (2021), indicated that aussurea lactone, eucalyptol, camphor, epicurzerenone, and -elemene metabolites of Curcuma aeruginosa Roxb. are new sources of anticancer agents also. Phytochemicals in the rhizomes of Zingiber officinale Roscoe such as gingerol, shogaol, zingiberol, and zingiberene have been shown to have antimicrobial, antiviral, anti-inflammatory, anti-hyperglicemia, and antitumor properties which are crucial for digestive disorder treatments (Ali et al. 2008). The Buyi community in China frequently uses Zingiber officinale Roscoe as an herbal medicine for the treatment of gastrointestinal diseases in livestock. If the temperature is cold or in the rainy season, giving a decoction of the Zingiber officinale Roscoe rhizome is very important to prevent animals from getting the flu (Xiong and Long 2020). As well as in Bojonegoro, if the environment is cold, cattle breeders will make a concoction of burnt Zingiber officinale Roscoe rhizomes for cattle to warm their bodies. The hyperthermic effect of Zingiber officinale Roscoe rhizomes is derived from polyphenols such as gingerol, 6-shogaol, 6-gingerol, and zingeron (Semwal et al. 2015; Sugimoto et al. 2018).

Cocos nucifera L. (coconut) water is most trusted by cattle breeders as a natural medicine for detoxification. Not only for cattle but also, the Javanese community generally believes that coconut water is a medicine with a myriad of benefits for neutralizing toxins in humans. Lima et al. (2015) explained that it has phytochemical activity includes anti-oxidant, anti-inflammatory, anti-microbial, anti-viral, anti-tumor, antifungal, and antihelmintic. Bhagya et al. (2012) show that tender coconut water (TCW) is rich in ascorbate acid, L-arginine, calcium, magnesium, and potassium, which can accelerate the sensitivity of insulin, regulate antioxidants, and lipid peroxidation inhibition. It is important to decrease oxidative stress, the source of inflammation. The high antioxidant agent is believed to be the main factor for detoxification. Minerals contained in coconut water can be a chelating agent that is able to bind toxic compounds to get out of the body immediately. In Fiji and India, water from Cocos nucifera L. has been proven to treat disorders of the kidneys and menstrual cycle. Other research results reveal that the water can be a renal and liver protective agent. The rats treated with coconut water presented decreased activities of the enzymes serum glutamate oxaloacetate transaminase and glutamate pyruvate transaminase. While rats treated with coconut water exhibit significant declines in calcium oxalate crystals, creatinine, blood urea nitrogen, lipid peroxidation, the enzyme activity of superoxide dismutase, and catalase (Sandhya et al. 2008; Gandhi et al. 2013).

Piper betle L. is a trusted medicinal plant that is trusted by cattle breeders as a natural medicine for the treatment of integumental disorders, especially for wound healing. This leaf is widely used to treat various types of wounds, such as those caused by insect bites, myiasis, and surgical wounds. Indeed, it has the potential as a source of healing skin and anti-aging agent. Many people have used it as a natural antiseptic to treat various disorders of the integument organs (Mgbeahuruike et al. 2017). According to Thi et al. (2021), Piper betle leaves have been shown to possess a phenolic component that has the capacity to heal cutaneous tissue wounds. A similar study found ethanolic extract of Piper betle L. was effective for healing acute wounds in rats (Rahayu et al. 2019). Several cattle breeders also mentioned that the leaves of this plant are crucially effective for treating diarrhea and detoxification. This is similar to research by Lutviandhitarani et al. (2015), which states that Piper betle L. leaves have good anti-oxidant and anti-bacterial activity because they contain phytochemichals such as eugenols, tannins, alkaloids, and terpenoids. The Javanese community believes that plants 
have good potential to heal wounds. Their use is also practical, namely by affixing the leaves to the wound or washing the wound with boiled water from leaves. This plant is easy to cultivate, usually spreads on the fence, and is also widely sold in traditional markets.

Both of Pandanus amaryllifolius Robx. and Pandanus tectorius Parkinson ex Du Roi has long been used as a natural pant remedy for lactation. When heifers give birth, the two plants are always given for the first time. Those leaves are crushed then brewed in warm water. The Javanese community usually uses Pandanus sp. to make food tasty and give a nice fragrant smell. Pandanus amaryllifolius Robx extract contains gallic acid, catechin, caffeic acid, myricetin, luteolin, and quercetin (Ghasemzadeh and Jaafar 2014). Reshidan et al. (2019) attested that their research shows that leaf water extract of Pandanus amaryllifolius Robx can improve metabolic syndrome. This is very closely related to preventing the emergence of metabolic syndrome that often occurs in heifers that have just given birth. Sometimes this syndrome causes the cattle to collapse, which greatly affects the decrease in lactation productivity, but this syndrome is rarely found in heifers in Bojonegoro, suspected of being given the medicinal concoction. Meanwhile, based on previous research, Pandanus tectorius Parkinson ex Du Roi contains phytochemical compounds in the form of flavonoids and triterpenoids, especially in the leaves (Omodamiro and Ikekamma 2016). These compounds contain a lot of potential as an anti-oxidant, hepatoprotective, anti-inflammatory, and antimicrobial agents. These potentials are believed to be able to facilitate the lactation of heifers in Bojonegoro. Antioxidant, antiinflammatory, and anti-microbial activity are mentioned as the main factors that play a role by inhibiting the occurrence of mastitis (Awad et al. 2019).

Plant Part Frequency of Leaves was a common component of herbal medicine in the Bojonegoro District by more than $58.00 \%$, while seed and sap were the least common $(2.50 \%)$. Similar to the other studies, leaves were an important component in traditional medicine in three districts of Pakistan's Lesser Himalayas (26.00\%), in Giresun Turkey (30.00\%), in Kohan Pakistan (47.00\%), in Jimma zone Ethiopia (68.12\%). It causes the leaves to be relatively easy to find and harvest, more convenient to formulate, and more renewable sources. Therefore making leaves perhaps more popular as herbal medicine (Abbasi et al. 2013; Guler et al. 2021; Tariq et al. 2014; Yigezu et al. 2014).

In contrast, a study conducted by Xiong and Long (2020) in Southwest Guizhou China discovered that the leaf is a less commonly used part of the medicinal plant $(11.00 \%)$ since roots are more well-known in that tribal community. Furthermore, studies in South Omo, Southern Ethiopia demonstrated that roots $(42.00 \%)$ are more edible as herbal medicine for their population because plant parts are available throughout the year, and it is the local beliefs that have a great therapeutic effect (Tolossa et al. 2013). Although the rhizome of Zingiberaceae species is the most commonly used medicinal plant in this study, the majority of medicinal plants mentioned by respondents are tree species with a lot of their leaves taken. Leaves are commonly used as medicinal plants because they are easier to apply, particularly in the form of solutions such as decoction, infusion, and tinctures made from boiled or brewed leaves in water.

The use of medicinal plants and other natural multicomponent medicines could be one strategy for reducing antibiotic use in cattle and decreasing antibiotic resistance (Bischoff et al. 2016). The use of antibiotics for the treatment of various diseases has been shown to be harmful, resulting in the establishment of antibiotic resistance in bacteria and a lot of residue on meat, which can undoubtedly threaten the health of humans who consume it in the long run. The emergence of multidrugresistant bacterial species required may need a highly restricted use of antibiotics in veterinary health practices (Mertenat et al. 2020). The substantial unfavorable effects of antibiotic use in cattle will almost certainly have an impact on the future use of therapeutic plants. During the pre-antibiotic era, a wide range of medicinal plants was utilized to treat animals. As a result, there is a need for the conservation of medicinal plants, which have a high potential for treating a variety of animal ailments. If there is a high demand for herbal medicine manufacture, a largescale investigation will not result in the extinction of a species of herbal plant species (El Sooud 2018).

\section{ACKNOWLEDGEMENTS}

This research was funded by a competitive grant on the Biodiversity, Faculty of Veterinary Medicine, Universitas Gadjah Mada, Yogyakarta, Indonesia with contract no. 1713/un1/fkh/hk4/2020.

\section{REFERENCES}

Abbasi AM, Khan SM, Ahmad M, Khan MA, Quave CL, Pieroni A. 2013. Botanical ethnoveterinary therapies in three districts of the Lesser Himalayas of Pakistan. J Ethnobiol Ethnomed 9 (1): 1-21. DOI: 10.1186/1746-4269-9-84

Ali BH, Blunden G, Tanira MO, Nemmar A. 2008. Some phytochemical, pharmacological and toxicological properties of ginger (Zingiber officinale Roscoe): a review of recent research. Food Chem Toxicol 46 (2): 409-420. DOI: 10.1016/j.fct.2007.09.085.

Al-Rubaei ZMM, Mohammad TU, Ali LK. 2014. Effects of local curcumin on oxidative stress and total antioxidant capacity in vivo study. Pak J Biol Sci 17 (12): 1237-1241. DOI: 10.3923/pjbs.2014.1237.1241

Asmara IY, Garnida D, Sulisytati M, Tejaningsih S, Partasasmita R. 2018. Ethnoveterinary medicine and health management of Pelung chicken in West Java, Indonesia. Biodiversitas 19 (4): 1502-1508. DOI: 10.13057/biodiv/d190441

Awada E, Austina D, Lyndona A, Awaad A. 2019. Possible effect of hala extract (Pandanus tectorius) on immune status, anti tumour and resistance to Yersinia ruckeri infection in rainbow trout (Oncorhynchus mykiss). Fish Shellfish Immunol 87: 620-629. DOI: 10.1016/j.fsi.2019.02.012

Aziz MA, Khan AH, Adnan M, Ullah H. 2018. Traditional uses of medicinal plants used by Indigenous communities for veterinary practices at Bajaur Agency, Pakistan. J Ethnobiol Ethnomed 14 (1): 118. DOI: $10.1186 / \mathrm{s} 13002-018-0212-0$

Badan Pusat Statistik Bojonegoro. 2015. Tinggi dari permukaan laut, hari dan rata-rata curah hujan di Kab. Bojonegoro. https://bojonegorokab.bps.go.id/statictable/2015/03/24/89/tinggi-dari- 
permukaan-laut-hari-dan-rata-rata-curah-hujan-di-kabbojonegoro.html. [Indonesian]

Badan Pusat Statistik Bojonegoro. 2016. Peternakan. https://bojonegorokab.bps.go.id/subject/24/peternakan.html\#subjekVi ewTab3. [Indonesian]

Badan Pusat Statistik Bojonegoro. 2018. Tenaga Kerja https://bojonegorokab.bps.go.id/subject/6/tenagakerja.html\#subjekViewTab4. [Indonesian]

Bakare AG, Shah S, Bautista-Jimenez V, Bhat JA, Dayal SR, Madzimure J. 2019. Potential of ethno-veterinary medicine in animal health care practices in the South Pacific Island countries: a review. Trop Anim Health Prod 52 (5): 2193-2203. DOI: 10.1007/s11250-019-02192-7

Bhagya D, Prema L, Rajamohan T. 2012. Therapeutic effects of tender coconut water on oxidative stress in fructose fed insulin resistant hypertensive rats. Asian Pac J Trop 5 (4): 270-276. DOI: 10.1016/S1995-7645(12)60038-8

Bischoff T, Vogl CR, Ivemeyer S, Klarer F, Meier B, Hamburger M, Walkenhorst M. 2016. Plant and natural product based homemade remedies manufactured and used by farmers of central Swiss cantons to treat livestock. Livest Sci 189: 110-125. DOI 10.1016/j.livsci.2016.05.003

Dassou GH, Ouachinou JM-AS, Adomou AC, Yédomonhan H, Tossou M, Favi A, Djidohokpin D, Gbèdolo E, Akoègninou A. 2020. Plant and natural product based homemade remedies for veterinary uses by the Peul community in Benin. J Ethnopharmacol 261: 113107. DOI 10.1016/j.jep.2020.113107

El Sooud KA. 2018. Ethnoveterinary perspectives and promising future. Int J Vet Sci 6 (1): 1-7. DOI: 10.1016/j.ijvsm.2018.04.001

Elfahmi, Woerdenbag HJ, Kayser O. 2014. Jamu: Indonesian traditional herbal medicine towards rational phytopharmacological use. J Herb Med 4 (2): 51-73. DOI: 10.1016/j.hermed.2014.01.002

Gandhi M, Aggarwal M, Puri S, Singla SK. 2013. Prophylactic effect of coconut water (Cocos nucifera L.) on ethylene glycol induced nephrocalcinosis in male wistar rat. Int Braz J Urol 39: 108-117. DOI: 10.1590/S1677-5538.IBJU.2013.01.14

Geck MS, Cristians S, Berger-Gonza 1ez M, Casu L, Heinrich M, Leont M. 2020. Traditional herbal medicine in Mesoamerica: Toward it evidence base for improving universal health coverage. Front Pharmacol 11: 1160. DOI: 10.3389/fphar.2020.01160

Ghasemzadeh A, Jaafar HZE. 2014. Optimization of reflux conditions for total flavonoid and total phenolic extraction and enhanced antioxidan capacity in pandan (Pandanus amaryllifolius Roxb.) using response surface methodology. Sci World J 1: 523120. DOI: $10.1155 / 2014 / 523120$.

Guler O, Polat R, Karakose M, Cakilcioglu U, Akbulut S. 2021. An ethnoveterinary study on plants used for the treatment of livestock diseases in the province of Giresun (Turkey). S Afr J Bot 142: 53-62. DOI: 10.1016/j.sajb.2021.06.003

Hossain CF, Al-Amin M, Sayem ASM, Siragee IH, Tunan AM, Hassan F Kabir MM, Sultana GNN. 2015. Antinociceptive principle from Curcuma aeruginosa. BMC Complement Altern Med 15 (1): 1-7. DOI: 10.1186/s12906-015-0720-6

Jadid N, Kurniawan E, Himayani CES, Andriyani, Prasetyowati I, Purwani KI, Muslihatin W, Hidayati D, Tjahjaningrum ITD. 2020. An ethnobotanical study of medicinal plants used by the Tengger tribe in Ngadisari village, Indonesia. PLoS ONE 15 (7): e0235886. DOI: 10.1371/journal.pone.0235886.

Jaguezeski AM, Perin G, Bottari NB, Wagner R, Fagundes MB Schetinger MRC, Morsch VM, Stein CS, Moresco RN, Barreta DA Danieli B, Defiltro RC, Schogor ALB, Da Silva AS. 2018. Addition of curcumin to the diet of dairy sheep improves health, performance and milk quality. Anim Feed Sci Technol 246: 144-157. DOI: 10.1016/j.anifeedsci.2018.10.010

Jayakumar S, Baskaran N, Arumugam R, Sathiskumar S, Pugazhenthi M 2018. Herbal medicine as a live practice for treating livestock ailments by indigenous people: A case study from the Konar community of Tamil Nadu. S Afr J Bot 118: 23-32. DOI: 10.1016/j.sajb.2018.06.002

Khan K, Rahman IU, Calixto ES, Ali N, Ijaz F. 2019. Ethnoveterinary therapeutic practices and conservation status of the medicinal flora of Chamla Valley, Khyber Pakhtunkhwa, Pakistan. Front Vet Sci 6: 122 DOI: $10.3389 /$ fvets.2019.00122

Kirmani NR, Banday MT, Abdullah, M. 2020. Ethno-medicinal plants used by Bakarwals for treatment of livestock. J Entomol Zool Stud 8 (3): 1742-1745.
Lima EBC, Sousa CNS, Meneses LN, Ximenes NC, Júnior MAS, Vasconcelos GS, Lima NBC, Patrocínio MCA, Macedo D, Vasconcelos SMM. 2015. Cocos nucifera (L.) (Arecaceae): A phytochemical and pharmacological review. BJMBR 48 (11): 953964. DOI: 10.1590/1414-431X20154773.

Lutviandhitarani G, Harjanti DW, Wahyono, F. 2015. Green antibiotic daun sirih (Piper betle 1.) sebagai pengganti antibiotik komersial untuk penanganan mastitis. Agripet 15 (1): 28-32. DOI: 10.17969/agripet.v15i1.2296 [Indonesian]

McGaw LJ, Famuyide IM, Khunoana ET, Aremu AO. 2020. Ethnoveterinary botanical medicine in South Africa: A review of research from the last decade (2009 to 2019). J Ethnopharmacol 257: 112864. DOI: $10.1016 /$ j.jep.2020.112864

Mertenat D, Cero MD, Vogl CR, Ivemeyer S, Meier B, Maeschli, A, Hamburger, M, Walkenhorst, M. 2020. Ethnoveterinary knowledge of farmers in bilingual regions of Switzerland - is there potential to extend veterinary options to reduce antimicrobial use? J Ethnopharmacol 246: 112184. DOI: 10.1016/j.jep.2019.112184

Mgbeahuruike EE, Yrjönen T, Vuorela H, Holm Y. 2017. Bioactive compounds from medicinal plants: Focus on Piper species. S Afr J Bot 112: 54-69. DOI: 10.1016/j.sajb.2017.05.007

Nurcholis W, Khumaida N, Bintang M, Syukur M. 2021. GC-MS analysis of rhizome ethanol extracts from Curcuma aeruginosa accessions and their efficiency activities as anticancer agent. Biodiversitas 22 (3): 1179-1186. DOI: 10.13057/biodiv/d220313

Omodamiro OD, Ikekamma CO. 2016. In vitro study of antioxidant and anticoagulant activities of ethanol extract of Pandanus tectorius leaves. Int Blood Res Rev 5 (1): 1-11. DOI: 10.9734/IBRR/2016/22231

Palanichamy P, Krishnamoorthy G, Kannan S, Marudhamuthu M. 2018. Bioactive potential of secondary metabolites derived from medicinal plant endophytes. Egypt J Basic Appl Sci 5: 303-312. DOI: 10.1016/j.ejbas.2018.07.002

Rahayu HSE, Nasruddin N, Nurani LH, Darmawati S, Rohmani A, Lutfiyati H, Wahyuningtyas ES, Sikumbang IM, Muhlisin Z, Sukeksi A, Nuroini F, Ishijima T, Sugama J, Nakatani T. 2019. Ethanolic extract of the natural product of Daun sirih (Piper betle) leaves may impede the effectiveness of the plasma jet contact style for acute wounds. Clin Plasma Med 15: 100090. DOI: 10.1016/j.cpme.2019.100090

Rahayu YYS, Araki T, Rosleine D. 2020. Factors affecting the use of herbal medicines in the universal health coverage system in Indonesia. J Ethnopharmacol 260: 112974. DOI: 10.1016/j.jep.2020.112974

Raza MA, Younas M, Buerkert A, Schlecht E. 2014. Ethno-botanical remedies used by pastoralists for the treatment of livestock diseases in Cholistan desert. Pak J Ethnopharmacol 151: 333-342. DOI: 10.1016/j.jep.2013.10.049

Reshidan NH, Muid SA, Mamikutty N. 2019. The effects of Pandanus amaryllifolius (Roxb.) leaf water extracts on fructose-induced metabolic syndrome rat model. BMC Complement Altern Med 19 (1): 1-13. DOI: 10.1186/s12906-019-2627-0.

Salinas-Rios T, Esqueda MTST, Cruz AD, Mora JLC, Perrusquía RG, Morales JLR, Velasco JLF, Bautista JH. 2017. Oxidative state of ewes with different number of parity during gestation and lactation. Pesq Vet Bras 37 (12): 1405-1410. DOI: 10.1590/s0100736x2017001200008

Sandhya VG, Rajamohan T. 2008. Comparative evaluation of the hypolipidemic effects of coconut water and lovastatin in rats fed fatcholesterol enriched diet. Food Chem Toxicol 46 (12): 3586-3592. DOI: $10.1016 /$ j.fct.2008.08.030

Sargin SA, Büyükcengiz, M. 2019. Plants used in ethnomedicinal practices in Gulnar district of Mersin, Turkey. J Herb Med 15: 100224. DOI: 10.1016/j.hermed.2018.06.003

Schnyder P, Schönecker L, Schüpbach-Regula G, Meylan M. 2019. Effects of management practices, animal transport and barn climate on animal health and antimicrobial use in Swiss veal calf operations. Prev Vet Med 167: 146-157. DOI: 10.1016/j.prevetmed.2019.03.007

Semwal RB, Semwal DK, Combrinck S, Viljoen AM. 2015. Gingerols and shogaols: Important nutraceutical principles from ginger. Phytochemistry 117: 554-568. DOI: 10.1016/j.phytochem.2015.07.012

Sharma R, Manhas RK, Magotra R. 2012. Ethnoveterinary remedies of diseases among milk yielding animals in Kathua, Jammu and Kashmir, India. J Ethnopharmacol 141: 265-272. DOI: 10.1016/j.jep.2012.02.027. 
Sugimoto K, Takeuchi H, Nakagawa K, Matsuoka Y. 2018. Hyperthermic effect of ginger (Zingiber officinale) extract-containing beverage on peripheral skin surface temperature in women. Evid-Based Compl Alt 1: 3207623 . DOI: $10.1155 / 2018 / 3207623$.

Sujarwo W, Keim AP, Savo V, Guarrera PM, Caneva G. 2015 Ethnobotanical study of Loloh: Traditional herbal drinks from Bali (Indonesia). J Ethnopharmacol 169: 34-48. DOI: 10.1016/j.jep.2015.03.079

Tariq A, Mussarat S, Adnan M, AbdElsalam NM, Ullah R, Khan AL. 2014. Ethnoveterinary study of medicinal plants in a tribal society of Sulaiman range. Sci World J. DOI: 10.1155/2014/127526

Teka A, Asfaw Z, Demissew S, Damme PV. 2020. Medicinal plant use practice in four ethnic communities (Gurage, Mareqo, Qebena, and Silti), south central Ethiopia. J Ethnobiol Ethnomed 16: 1-2. DOI: 10.1186/s13002-020-00377-1

Thakur M, Asrani RK, Thakur S, Sharma PK, Patil RD, Lal B, Parkash O. 2016. Observations on traditional usage of ethnomedicinal plants in humans and animals of Kangra and Chamba districts of Himachal Pradesh in North-Western Himalaya, India. J Ethnopharmacol 191: 280-300. DOI: 10.1016/j.jep.2016.06.033

Theanphong O, Mingvanish W, Kirdmanee C. 2015. Chemical constituents and biological activities of essential oil from Curcuma aeruginosa Roxb. rhizome. Bull Heal Sci Technol 13: 6-16.

Thị CHC, Nguyễn HD, Hoang DML. 2021. Influence of Piper betle L. extract on umbilical cord cells in vitro and potential treating cutaneous wound. Heliyon 7 (2021): e06248. DOI: 10.1016/j.heliyon.2021.e06248.
Tizabi Y, Hurley LL, Qualls Z, Akinfiresoye, L. 2014. Relevance of the anti-inflammatory properties of curcumin in neurodegenerative diseases and depression. Molecules 19 (12): 20864-20879. DOI: 10.3390/molecules191220864

Tolossa K, Debela E, Athanasiadou S, Tolera A, Gangga G, Houdjik JGM. 2013. Ethno-medicinal study of plants used for treatment of human and livestock ailments by traditional healers in South Omo, Southern Ethiopia. J Ethnobiol Ethnomed 9 (1): 1-15. DOI: 10.1186/1746-4269-9-32

Wang X, Gao J, Wang Y, Zhao B, Zhang Y, Han F, Zheng Z, Hu D. 2017. Curcumin pretreatment prevents hydrogen peroxide-induced oxidative stress through enhanced mitochondrial function and deactivation of Akt/Erk signaling pathways in rat bone marrow mesenchymal stem cells. Mol Cell Biochem 443 (1): 37-45. DOI: $10.1007 / \mathrm{s} 11010-017-3208-5$

World Health Organization. 2010. Climate Change and Human Health. http://www.who.int/globalchange/ecosystems/biodiversity/en/index.ht $\mathrm{ml}$.

Xiong Y, Long, C. 2020. An ethnoveterinary study on medicinal plants used by the Buyi people in Southwest Guizhou, China. J Ethnobiol Ethnomed 16 (1): 1-20. DOI: 10.1186/s13002-020-00396-y

Yigezu Y, Haile DB, Ayen WY. 2014. Ethnoveterinary medicines in four districts of Jimma zone, Ethiopia: cross sectional survey for plant species and mode of use. BMC Vet Res 10 (1): 1-12. DOI: $10.1186 / 1746-6148-10-76$ 